\title{
EVALUATION OF DIFFERENT DEHYDRATION METHODS OF COOKED MUSSELS
}

\author{
G. TRIBUZI ${ }^{1}$ and J. B. LAURINDO ${ }^{1}$
}

1 Federal University of Santa Catarina, Department of Chemical and Food Engineering, EQA/CTC/UFSC, 88040-900, Florianópolis - SC, Brazil.

E-mail: joao@enq.ufsc.br

\begin{abstract}
The development of new products with high quality and added value is of great importance for the food industry. The aim of this work was to study different drying methods (freeze drying (FD), vacuum drying (VD), and air drying (AD)) and the rehydration capacity (RC) of cooked mussels' meat. The temperature of the sample holder plate during FD was set at four levels: $15,30,40{ }^{\circ} \mathrm{C}$ and non heated condition. VD and AD processes were carried out at $40{ }^{\circ} \mathrm{C}$. Dried mussels were rehydrated in distilled water at 20 ${ }^{\circ} \mathrm{C}$ and $80{ }^{\circ} \mathrm{C}$. In the FD process the mild heating of the sample holder plate $\left(15^{\circ} \mathrm{C}\right)$ produced a considerable increase in the drying rate without modifying the aspect of the sample. The RC of AD and VD-mussels was about $30 \%$ lower than the FD at $20{ }^{\circ} \mathrm{C}$ and of about $10 \%$ lower at $80{ }^{\circ} \mathrm{C}$. The maximum $\mathrm{RC}(\approx 90 \%$ of the initial weigh) was obtained with freeze dried mussel in water at $20{ }^{\circ} \mathrm{C}$.
\end{abstract}

\section{INTRODUCTION}

Perna perna mussel is one of the most important commercial mollusk species cultivated in Brazil. A factor that limits its commercialization in fresh or pre-cooked forms is its short shelf life. To overcome this problem, the development of new products with increased shelf life is very important. Drying is an alternative largely used to extend the shelf life of foods. When water content and water activity of foods are reduced to low levels, the microbiological growth and other deteriorative reactions are also reduced, thus promoting longer shelf life (Ibarz and Barbosa-Cánovas, 2003). Many drying technologies are available in the industry, and can be classified into two groups: in-air (atmospheric) and in-vacuum drying processing. The most diffused and traditional process is the air-drying. In this process the drying rate increases for high temperatures and air flow, and for low gas relative humidity. The vacuum drying started to be used in the first half of the twentieth-century. In this method the moisture removal is facilitate by the pressure gradient and is adequate when the presence of air and high temperatures can damage the nutritive and functional properties of the processed product (Chen and Mujumdar, 2008). In particular, vacuum freeze drying is an alternative for thermal sensitive foods. Frozen water maintains the structural integrity during freeze drying, avoiding collapse and leading to a highly porous structure (Ibarz and Barbosa-Cánovas, 2003; Ratti, 2008). In fact, freeze dried foods recover original shape, taste and aroma when rehydrated, resulting in high quality products (Ibarz 


\section{9 a 22 de outubro de 2014 \\ Florianópolis/SC}

and Barbosa-Cánovas, 2003). These advantages are balanced by the energy-cost aspects of the product freezing and high vacuum requirements (Singh and Heldman, 2009).

Few studies of seafood drying were found in literature. The influence of air temperature on the drying kinetics, rehydration capacity, and other physical-chemical properties of salted jumbo squid fillets during convective dehydration in the temperatures range from 50 to $90{ }^{\circ} \mathrm{C}$, was investigated by Vega-Gálvez et al. (2011). Drying temperature effect was noticeable on drying rate and on color indexes, rehydration capacity, and texture of dried squid. High drying temperatures showed a negative effect on the rehydration index. However, texture indexes were positively affected by increasing the air-drying temperature probably because of changes in food protein matrix. Niamnuy et al. (2007) studied the drying process of shrimps in a jet-spouted bed dryer. The effect of various parameters (concentration of salt, size, cooking time, and drying air temperature) was investigated upon the kinetics of drying and various quality attributes of shrimps during drying. The drying temperature showed a significant effect on the drying kinetics increasing the rate of dehydration. In terms of quality, it was found that higher concentration of salt solution, longer boiling time, and larger size of shrimp led to more shrinkage and toughness of dried shrimp but to less rehydration ability. Crapo et al. (2010) developed a method for producing freeze dried salmon cubes. The process was divided in two stages, studying the effect of temperature variation on the drying kinetics and on physical characteristics of the final product including bulk density, shrinkage, hardness, color, and rehydration kinetics. The processing time required to reach moisture content lower than $10 \%$ and a water activity lower than 0.4 was between 8.5 to 11 hours. The developed product presented instantaneous rehydration properties. Rehydration is a very important property of dried seafood. This property can be affected by dried foods porosity and structure and by the soaking water temperature and $\mathrm{pH}$ (Rahman and Perera, 2007). In literature are reported data about rehydration of cod (Bjørkevoll, Olsen, and Olsen, 2004; Barat et al., 2004; Nguyen et al., 2012a; Nguyen et al., 2012b), jumbo squid (Vega-Gálvez et al., 2011), tilapia (Duan et al., 2011), and sea cucumber (Duan et al., 2010).

The dehydration seems to be an interesting method to add value and to enhance the shelf life of mussel meat. However, there are few studies in the literature regarding drying and rehydration of mussel meat. Thus, the objective of this study was to investigate the influence of drying method (FD, VD, and $\mathrm{AD}$ ) on the drying rate and $\mathrm{RC}$ of mussel meat rehydrated at two different water temperatures.

\section{MATERIALS AND METHODS}

\subsection{Sample preparation}

Live mussels (Perna perna) were purchased from aquaculture farms on the coast of Santa Catarina (state, Brazil). Fresh samples were rapidly transported to the laboratory, cleaned from superficial incrustations and cooked for 5 min in steam at $100{ }^{\circ} \mathrm{C}$ at atmosphere pressure. After cooking, mussels were cooled by immersion in a water/ ice mixture for $5 \mathrm{~min}$. Then, the mussel meat was carefully separated from the shells with a knife, preserving its integrity. Cooked-cooled mussel meat samples with weight of $8 \pm 2 \mathrm{~g}$ and anatomical integrity were selected and stored in 

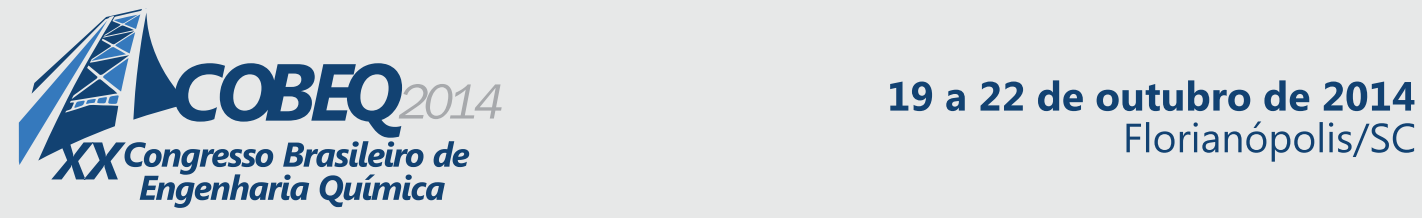

a refrigerator at $4 \pm 1{ }^{\circ} \mathrm{C}$ until processing.

\subsection{Experimental devices}

FD was performed in a freeze dryer (model L101, Liotop, Brazil) adapted to allow the online monitoring of sample weight and the temperature control of the sample holder plate (SHP) during processing (Tribuzi, 2013). The weighting system was composed by a single-point load cell (model GL, Alfa Instrumentos, Brazil), with nominal capacity of $2 \mathrm{~kg}$ and sensitivity of $0.1 \mathrm{~g}$, connected to a signal conditioning system (model 3101C, Alfa Instrumentos, Brazil). The load cell outputs were recorded every 30 seconds by a computer. The SHP, connected to the load cell by a stem, was heated by an electric resistance; its temperature was measured by a thermocouple (mod. PT100) and controlled by a PID control system (Dist, Produtos para Laboratório, Brazil). The cover of the equipment was the physical support for the weight measurement system and for the SHP. The connection through the cover of the wires of thermocouples, load cell and electrical resistance were made with copper screw sealed with resin, to allow the maintenance of the vacuum condition.

AD was performed in an air circulation and renovation oven (TECNAL-TE 394/2, Brazil). The air velocity was of $\approx 1 \mathrm{~m} / \mathrm{s}$, measured with a compact thermal anemometer (Testo, 425, Germany) and the RH was of $55 \% \pm 5$ measured with a thermohygrometer (Texto, 610, Germany). VD was carried out in a vacuum oven (TECNAL-TE 395, Brazil) at the pressure of $\approx 15$ mbar. The online weighting system composed by SHP and load cell was adapted and used in weight monitoring during $\mathrm{AD}$ and $\mathrm{VD}$.

\subsection{Experimental setup}

Freeze drying: Before FD, mussels were frozen until reaching, in the core, the temperature of $-50 \pm 5{ }^{\circ} \mathrm{C}$. About $120 \mathrm{~g}$ of frozen samples were equally and rapidly distributed in the SHP and the vacuum pump was started reaching the operative pressure of about 0.2 mbar. After $20 \mathrm{~h}$ of FD, the atmospheric pressure was restored; samples were removed and final moisture content and $\mathrm{a}_{\mathrm{w}}$ were determined. The temperature of the SHP during FD processes was set in four levels: nonheated condition, 15,30 , and $40{ }^{\circ} \mathrm{C}$. The experiments were performed in triplicate for each SHP condition.

Vacuum and air drying: VD and $\mathrm{AD}$ were realized at the temperature of $40{ }^{\circ} \mathrm{C}$. Approximately 120 of cooked samples were spread on the SHP and dried for $24 \mathrm{~h}$. At the end of the process samples were removed and final moisture content and $\mathrm{a}_{\mathrm{w}}$ were determined. In both cases the experiments were performed in triplicate.

Rehydration: Dried samples were rehydrated and the RC was calculated. Samples obtained using different drying process, with average moisture of $10 \%$, were packaged in nylon nets and totally immersed in distillated water $(1: 50-\mathrm{g}$ dried mussel: $\mathrm{g}$ water $)$. The water temperature effect was also investigated at $20^{\circ} \mathrm{C}$ and $80{ }^{\circ} \mathrm{C}$. Sample weight was measured after 1, 2, 3, 4, 6, $8,10,15,20,25$ and 30 min of immersion for FD samples and after 3, 6, 10, 15, 20, 25, 30, 40, $50,60,90$, and 120 min for $\mathrm{VD}$ and $\mathrm{AD}$ samples to calculate the RC (Equation 1). 


\section{9 a 22 de outubro de 2014 \\ Florianópolis/SC}

$$
R C=W_{a} / W_{i} * 10
$$

in which $W_{a}$ is the mass of water absorbed during rehydration and $W_{i}$ is the water lost during drying (Lewicki, 1998). The experiments were performed in triplicate for each condition.

Analytical determinations: The moisture content of samples was determined using the gravimetric method (AOAC, 2000). The water activity was measured with a dew-point hygrometer (Aqualab Model Series 3, Decagon Devices Inc., Pullman, USA). All analytical determinations were performed in triplicate.

\section{RESULTS AND DISCUSSION}

The experimental data of moisture content as function of time obtained with the on line weighting system for the different drying methods presented good reproducibility in all cases.

Figure 1 shows the drying curves (a) and the drying rates as function of time (b) and moisture content (c) of freeze drying of mussel meat recorded at different SHP temperature (15, $30,40{ }^{\circ} \mathrm{C}$ and non-heated condition). For better visualization, only a representative curves, for each condition, were presented.
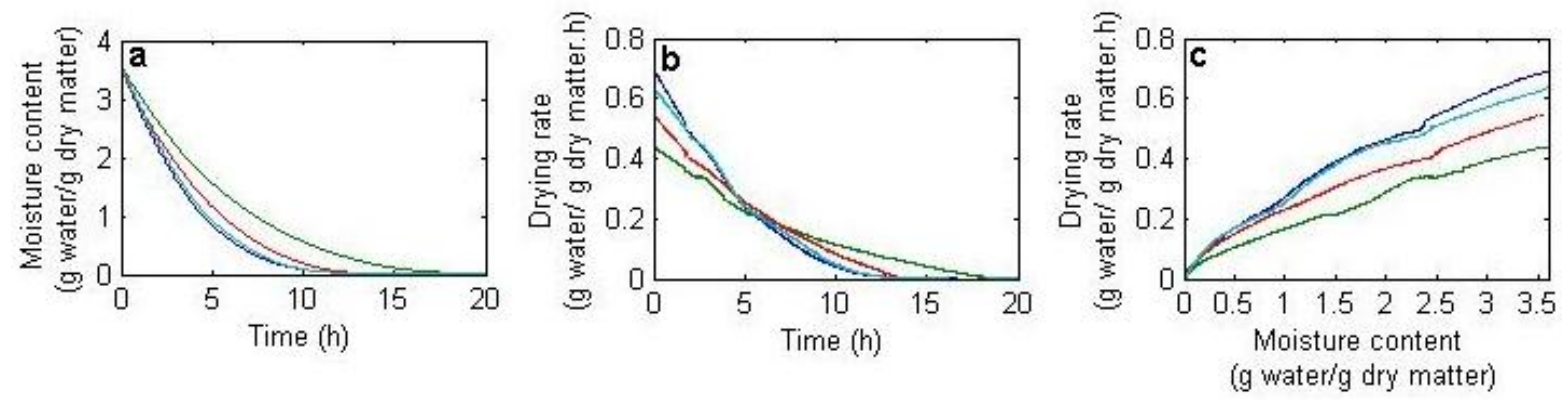

Figure 1 - FD curves (a), FD rate as function of time (b), and FD rate as function of moisture content (c) of mussel meat at the SHP temperature of non-heated condition $(-), 15^{\circ} \mathrm{C}(-), 30^{\circ} \mathrm{C}$ $(-)$, and $40{ }^{\circ} \mathrm{C}(-)$.

The equilibrium moisture content was reached after 19.8, 16.5, 15.9, and 15 hours with the SHP set in the conditions of non-heated, 15,30 , and $40{ }^{\circ} \mathrm{C}$, respectively. The moisture content at the end of the process was of $0.017,0.014$ and 0.015 ( $\mathrm{g}$ water/g dry matter) with the SHP at 15, 30 , and $40{ }^{\circ} \mathrm{C}$, respectively. The final moisture content of mussels dried with the non-heated SHP was of 0.043 (g water/g dry matter). In freeze dried mussel meat the value of $0.11 \pm 0.01$ (g water/g dry matter), considered acceptable for dried seafood (Crapo et al., 2010), was reached after 11.3, 10.4 and 9.3 hours of drying at the SHP temperature of 15,30 , and $40{ }^{\circ} \mathrm{C}$, respectively. When the heating system was switched off, the drying time required to reach the objective moisture content was of 15.1 hours. The $\mathrm{a}_{\mathrm{w}}$ of the products at this moisture content was not influenced by the SHP temperature resulting on average of $0.270 \pm 0.053$. The drying rates 


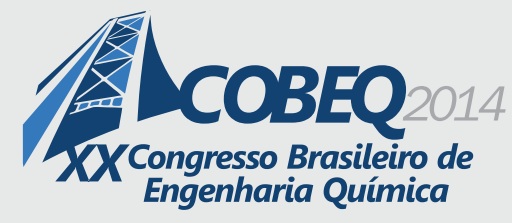

19 a 22 de outubro de 2014
Florianópolis/SC

(Figure $1 \mathrm{~b}$ and $1 \mathrm{c}$ ) presented a decreasing drying rate for all the studied conditions. The primary and secondary periods of drying were not clearly identifiable. This fact confirms that, in the freeze drying of biological materials, these drying stages occur simultaneously (Liapis and Bruttini, 2006). The temperature of the SHP affected significantly the drying rate, particularly in the early stages of drying. After $\approx 5 \mathrm{~h}$ of processing the drying rate at the SHP temperature of 15 , 30 , and $40{ }^{\circ} \mathrm{C}$ becomes similar. The latent heat required to the ice sublimation was provided by conduction (SHP) and radiation (SHP and environment). As the drying process proceeds a dry layer is formed on the surface of the sample. This dry layer behaves as an insulating material, reducing the contribution of the radiation on the heat transfer to the sublimation front (Tribuzi, 2013).

The figures $2 \mathrm{a}, 2 \mathrm{~b}$, and $2 \mathrm{c}$ show, respectively, drying curves, drying rate as function of time and as function of moisture content, of VD and AD processes.
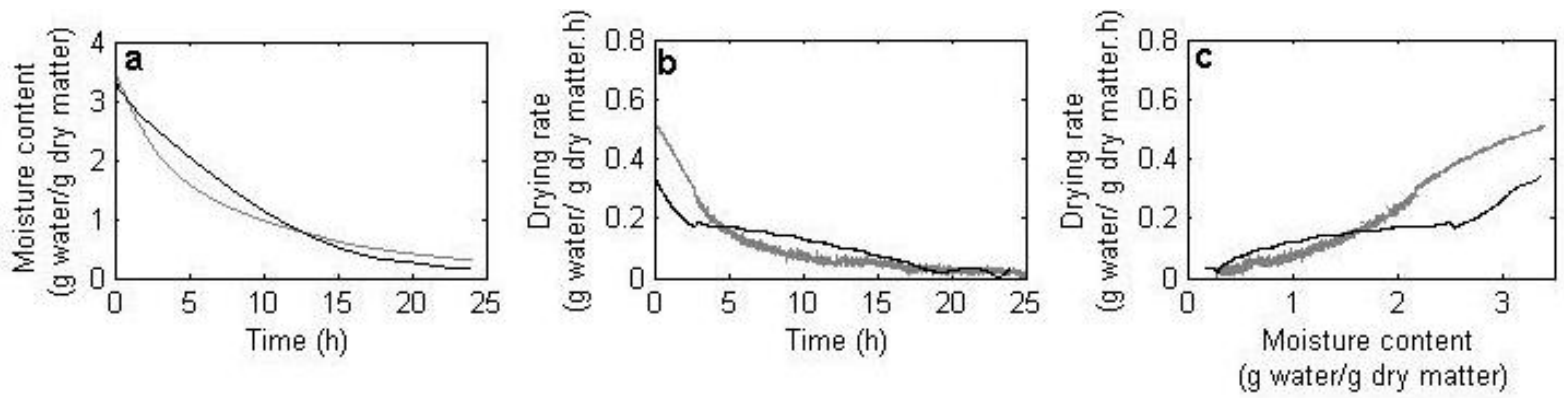

Figure 2 - Drying curves (a), drying rate as function of time (b), and drying rate as function moisture content $(\mathrm{c})$ of mussel meat air $(-)$ and vacuum dried (-).

The moisture content of dried mussels after $24 \mathrm{~h}$ of drying was of $0.18 \pm 0.05$ and $0.11 \pm 0.03$ (g water/g dry matter), respectively for air and vacuum dried samples. The $\mathrm{a}_{\mathrm{w}}$ of AD and VD mussels after $24 \mathrm{~h}$ of drying was of $0.401 \pm 0.015$ and $0.250 \pm 0.012$, respectively. The values of $\mathrm{a}_{\mathrm{w}}$ of vacuum dried mussels did not differed from those of obtained in freeze dried samples. However, the values of $\mathrm{a}_{\mathrm{w}}$ of AD mussel were significantly higher of those of mussels obtained in FD and VD processes. Considering that the $a_{w}$ value of 0.6 is the limit for microbial growth (Labuza et al., 1970) the AD mussels can be considered microbiologically stables at room temperature, however other degradative reactions (lipid oxidation and enzymatic activity) could take place on storage. The drying method (AD and VD) influenced significantly the drying rate of pre-cooked mussel meat. The drying rates (Figure $2 b$ and $c$ ) show clearly two falling rate periods for both methods. The drying rate during AD was higher than that of VD in the first five hours of drying. Then, the AD rate decreased and stabilized to lower levels with respect to the VD rate. This rate change started approximately after 4 hours of process. The absence of a constant drying rate period could be justified by the formation of the case hardening on the samples. This layer formed on the sample surface make difficult the diffusion of water to the surface decreasing the drying rate. This phenomenon is more intense in AD than in VD (Ratti, 2001), as confirmed by the higher drying rate presented in the second part of the VD. 
Mussels dried with the different methods were rehydrated in distilled water at $20{ }^{\circ} \mathrm{C}$ and $80{ }^{\circ} \mathrm{C}$. The results were expressed in rehydration capacity and are presented in Figure 3.
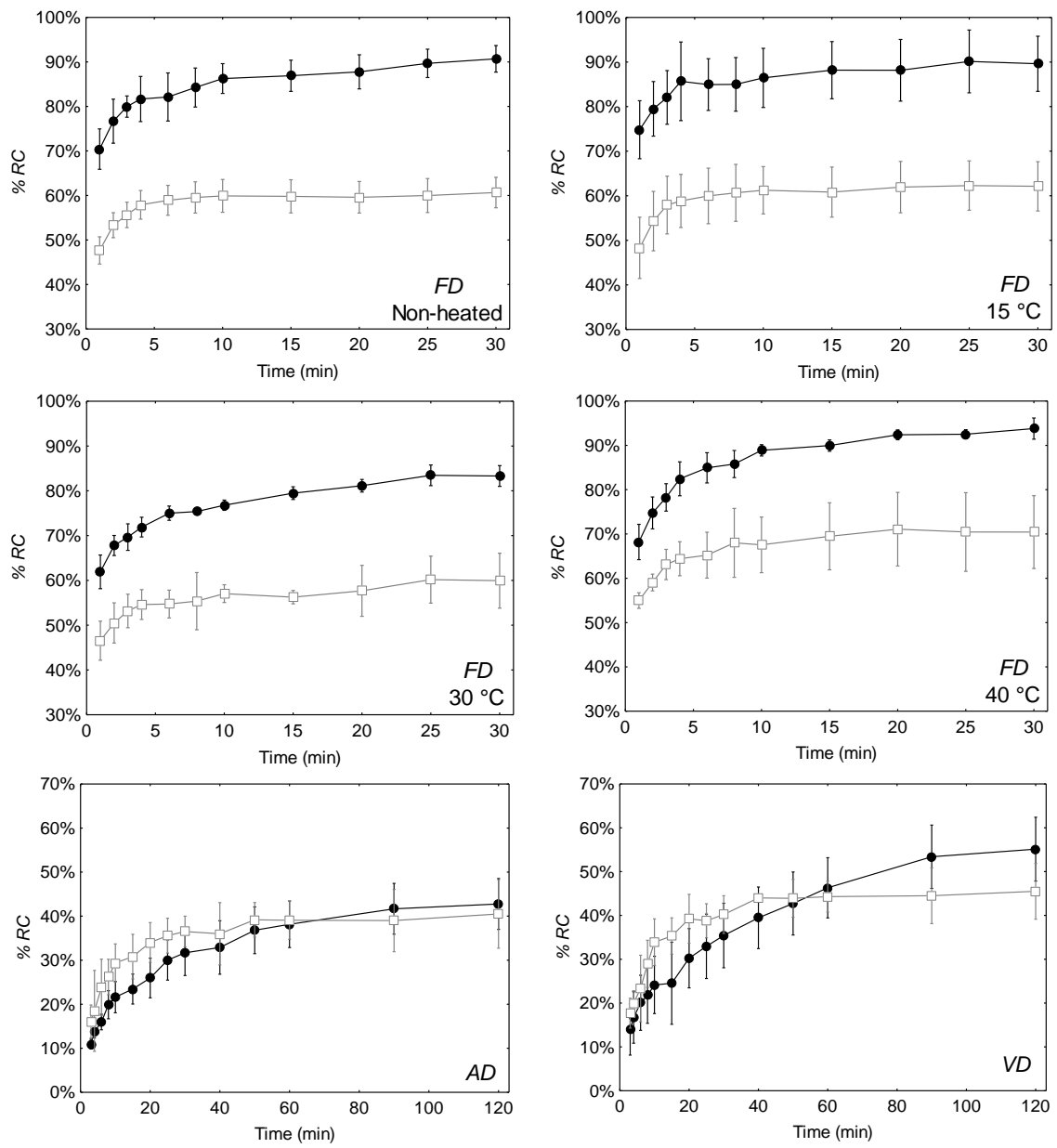

Figure 3 - Rehydration capacity kinetics of dried mussels obtained for the different drying methods (FD, VD, and AD) and rehydrated in water at $20^{\circ} \mathrm{C}(\bullet)$ and $80{ }^{\circ} \mathrm{C}(\square)$

The water temperature affected the RC of the FD mussel meat that showed higher $\mathrm{RC}(\approx 20$ $\%)$ at lower water temperature when compared to the samples rehydrated at higher temperature. On the other hand, the SHP temperature during FD did not show any effect on the RC. For mussels dried with the other two methods the RC was higher with warm water in the first hour of rehydration, than the situation revert and the RC presented higher values for mussels rehydrated in cold water. The VD presented a tendency of a higher rehydration capacity than the AD mussels. The RC of the AD and VD mussels was on average $30 \%$ lower than the RC of FD mussels at the water temperature of $20^{\circ} \mathrm{C}$ and of about $10 \%$ lower at the water temperature of $80{ }^{\circ} \mathrm{C}$ at the end of the respective processes. It is possible to suppose that at the higher water temperature the protein structure of the mussel suffer an intense denaturation that could cause smaller water uptake. The lower values of the RC found in VD and AD mussels with respect to 
the values of RC found form FD mussels are easily explainable considering the great modification of the microstructure that occurs during VD and AD. Deng et al. (2013) studied the water distribution during rehydration of freeze dried and air dried squid filets, using nuclear magnetic resonance analysis. The water migration from the periphery to the internal region of the product was affected by the microstructure. At the same rehydration time, in freeze dried samples the water was uniformly distributed in the product, when in air dried samples the water penetration was barely visible.

\section{CONCLUSION}

Mussel meat drying is a process that adds value and enhances the shelf life of this product. In this study was demonstrate that, in the studied conditions, with freeze drying it is possible to obtain product with good quality in less time that the air and vacuum drying. Moreover, the freeze drying time can be considerably reduced raising the sample holder plate temperature. The rehydration capacity of the dried mussels is influenced by both the drying method and the temperature of the water. With water at higher temperature, the RC is considerably lower than with cold water, especially for FD samples. A rehydration capacity of about $90 \%$ of the initial weigh can be obtained with freeze dried mussel in water at $20^{\circ} \mathrm{C}$.

\section{REFERENCES}

AOAC. Official Methods of Analysis. Association of Official Analytical Chemists, Washington, 2000.

BARAT, J.; RODRÍGUEZ-BARONA, S.; ANDRÉS, A.; VISQUERT, M. Mass transfer analysis during the cod desalting process. Food Res. Int., 37(3), 203-208, 2004.

BJØRKEVOLL, I.; OLSEN, J.; OLSEN, R. Rehydration of salt-cured cod using injection and tumbling technologies. Food Res. Int., 37(10), 925-931, 2004.

CHEN, X. D.; MUJUMDAR, A. S. Drying Technologies in Food Processing. Wiley-Blackwell, 2008.

CRAPO, C.; OLIVEIRA, A.; NGUYEN, D.; BECHTEL, P.; FONG, Q. Development of a Method to Produce Freeze-Dried Cubes from 3 Pacific Salmon Species. J.Food Sci., 74(5), 267-275, 2010.

DENG, Y.; LUO, Y.; WANG, Y.; YUE, J.; LIU, Z.; ZHONG, Y.; ZHAO, Y.; YANG, H. Drying induced protein and microstructure damages of squid fillets affected moisture distribution and rehydration ability during rehydration. J. Food Eng., 123, 23-31, 2014.

DUAN, X.; ZHANG, M.; MUJUMDAR, M.; WANG, S. Microwave freeze drying of sea cucumber (Stichopus japonicus). J. Food Eng., 96, 491-497, 2010.

DUAN, Z.; JIANG, L.; WANG, J.; YU, X.; WANG, T. Drying and quality characteristics of tilapia fish fillets dried with hot air-microwave heating. Food Bioprod. Process., 89(4), 472476, 2011. 
IBARZ, A.; BARBOSA-CÁNOVAS, B. Unit operations in food engineering. CRC Press LLC, 2003.

LABUZA, T.; TANNENBAUM, S.; KAREL, M. Water content and stability of low moisture and intermediate. Food Tech., 24, 543-550, 1970.

LEWICKI, P. Some Remarks on Rehydration of Dried Foods. J. Food Eng., 36, 81-87, 1998.

LIAPIS, A.; BRUTTINI, R. Freeze Drying. In: A. Mujumdar, Handbook of Industrial Drying (Third Edition ed., pp. 257-271). CRC Press, 2006.

NGUYEN, M.; JONSSON, J.; THORKELSSON, G.; ARASON, S.; GUDMUNDSDOTTIR, A.; THORARINSDOTTIR, K. Quantitative and qualitative changes in added phosphates in cod (Gadus morhua) during salting, storage and rehydration. LWT-Food. Sci. Technol., 47, 126-132, 2012a.

NGUYEN, M.; THORARINSDOTTIR, K.; THORKELSSON, G.; GUDMUNDSDOTTIR, A.; ARASON, S. Influences of potassium ferrocyanide on lipid oxidation of salted cod ( Gadus morhua) during processing, storage and rehydration. Food Chem., 131, 1322-1331, 2012 b.

NIAMNUY, C.; DEVAHASTIN, S.; SOPONRONNARIT, S. Effects of Process Parameters on Quality Changes of Shrimp During Drying in a Jet-Spouted Bed Dryer. J.Food Sci., 72(9), 553-563, 2007.

RAHMAN, M.; PERERA, C. O. Drying and food preservation. In: M. S. RAHMAN, Handbook of Food Preservation (Secon edition ed., pp. 403-430). New York, CRC Press, 2007.

RATTI, C. Freeze and vacuum drying of foods. In: X. Chen, and A. Mujumdar, Drying Technologies in Food Processing (pp. 225-243). Blackwell Publishing, 2008.

RATTI, C. Hot air and freeze-drying of high-value foods: a review. J. Food Eng., 49, 311-319, 2001.

SINGH, R.; HELDMAN, D. Introduction to Food Engineering (Fourth Edition ed.). London: Academic Press Inc, 2009.

TRIBUZI, G. Desenvolvimento de alternativas tecnológicas para o processamento e conservação da carne de mexilhão. Ph.D. thesis, Federal University of Santa Catarina, 2013.

VEGA-GÁlVEZ, A.; MIRANDA, M.; CLAVERÍA, R.; QUISPE, I.; VERGARA, J.; URIBE, E.; PAEZ, H.; SCALA, K.D. Effect of air temperature on drying kinetics and quality characteristics of osmo-treated jumbo squid (Dosidicus gigas). LWT-Food. Sci. Technol., 44(1), 16-23, 2011. 